\title{
THE ORGANIZATION OF GEOLOGICAL EDUCATION IN CHINA
}

\author{
by Chi Ji-Shang
}

\begin{abstract}
Since the founding of the People's Republic of China in 1949, more than 128000 geologists have graduated from 46 Chinese universities and geological colleges and larger numbers from the workers' training schools and the nearly 80 geological high schools. This article reviews the present structure of geoscience education in China on five levels: youth activities, classes in middle schools, secondary education in special geological and technical schools, higher education in universities and geological colleges with their correspondence and night courses, and international academic exchanges. The colossal achievements of the Chinese in training earth scientists deserve careful notice by other countries determined to build a strong geoscience community.
\end{abstract}

\section{Background}

Geological education began in China in 1909 in the Geological Branch (Dizhimen) of Jingshi University, now known as the Department of Geology of Beijing University. Nevertheless the statistics in 1949 showed that China up to then had only about 200 geologists, equipped with 14 drilling machines.

Since the founding of the People's Republic of China in 1949, the government has placed more emphasis on geological education. As a result, there are now in China 7 geological colleges, 39 universities with departments or specialities of geology, and 78 geological senior high schools as well as geological workers' training schools. A total of 68329 students have graduated from universities and colleges of geology, making up $2.3 \%$ of the total graduates of the country, and there are 60880 graduates from the geological schools. The statistics in 1978 showed that 576 postgraduate geology students had completed their courses, and the number has been going up steadily since 1981. Most of these have received their master's degrees and some continue studying for a doctorate.

The education of geology in China would have made more progress were it not for the chaos in the period from 1966 to 1976, because colleges had to stop enrolling students from 1966 to 1971 . It was not until 1978 that the education of geology began to progress properly. Now the plan is to enroll more graduate students in the coming years to meet the needs of the four "modernizations": industry, agriculture, national defence and science and technology.

\section{Youth Activities}

In order to awaken an interest in the earth sciences from an early age the Geological Society of China and its various professional committees have sponsored many activities for children and youth. These include summer camps and geological excursions, visits to geological museums, compilation of popular science books, radio and TV programs, and picture galleries on geology. For example, in 1981 the Society organized a "National Summer Camp of Geology for Juve-

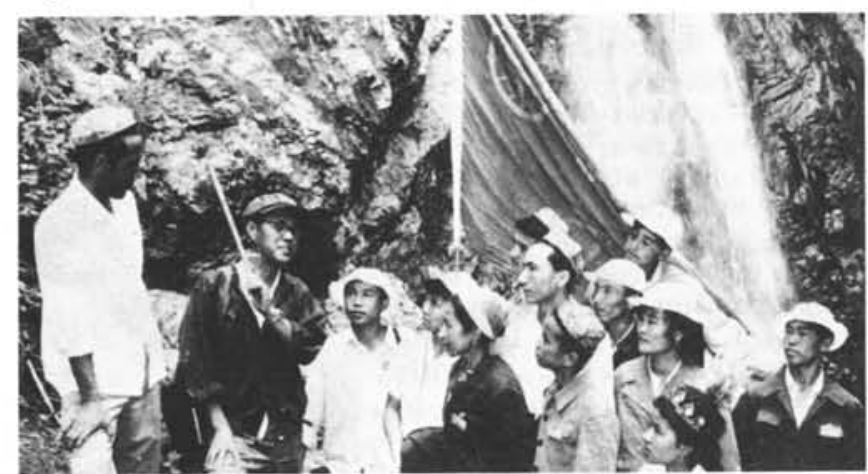

Summer youth camp (1982). A counsellor explains an outcrop in Baiyanggou, Xinjiang Province. niles", setting up 30 camps throughout the country in which 3100 young geology enthusiasts and their counsellors took part. They wrote over 2000 articles concerning geology and collected about 10000 rock and mineral specimens. In 1982, the number of participants in summer camps has increased to about 4900 .

In Shanghai, 500 school teachers of geography have been trained in geology so that it could be included in the geography course of all middle schools. The local geological society branch, together with several other groups, recently sponsored a "Middle School Students' Competition on Rock and Mineral Identification" with 365 competitors from 90 middle schools. Many youngsters become inspired by these activities and decide to devote their lives to earth science. Indeed, in 1982 an increasing number of middle school graduates chose colleges of geology as their first choice for higher education.

\section{Geological Schools}

In the 1970 s geological schools and technical workers' schools offered a two-year education leading to a diploma, but the standard has now been raised in some to the level of junior colleges. The schools of fer more than 10 specialities including geological surveying and mineral exploration, geophysical prospecting, geochemical prospecting and petroleum exploration. There are 2044 teaching staff in these schools, which is 20 times that of 1952. Graduates from these schools become geologists or technical workers in the geological teams, or lab technicians and equipment operators in colleges and scientific institutes.

\section{Colleges and Universities}

Colleges of geology conduct a 4-year Bachelor degree program, with an additional 2 or 3 years for a master's degree, and 3 more years for a doctorate. To the end of 1979 there were 5445 geology teachers in colleges. Of these 1195 were ranked as lecturers, and 286 as professors and associate professors. Colleges of geology are administered jointly by the Ministry of Education and other ministries concerned such as Geology and Mineral Resources, Metallurgical Industry, Petroleum, and Coal Industry. Departments of geology in universities on the other hand are under the direct administration of the Ministry of Education except for the Department of Geology in the University of Science and Technology of China, which is managed by both the Ministry of Education and Academia Sinica.

Graduates trained in colleges of geology greatly exceed those in the departments of geology in universities, and among the colleges of geology those under the Ministry of Geology and Mineral Resources have the largest enrolment. Most graduates get job assignments from geological teams in one part of the country or another. A few will continue their studies for master's and doctorate degrees, following which they will work at colleges and research institutes.

Wuhan College of Geology, the largest of all, can be cited as 

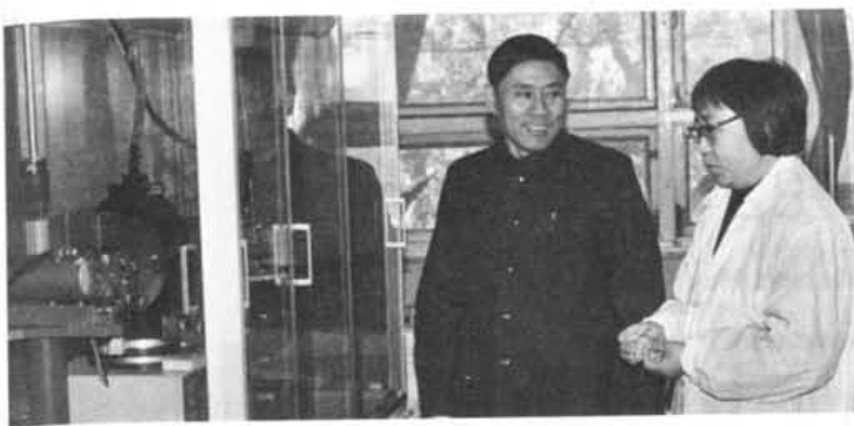

Professor Penq Zhi-zhong (left) of Wuhan College of Geology discusses with a colleaque the crystal structure of the new mineral Yimenqkuang near the single crystal refractometer.

an example. The following specialities are taught: physical geology, stratigraphic palaeontology, mineralogy and petrology, geomechanics, geochemistry, mineral deposits, coal geology, petroleum and natural gas, chemical analysis of rocks and minerals, hydrogeology, engineering geology, geophysics, geophysical prospecting for oil and gas, drilling engineering, exploration machinery and exploration excavating engineering.

Throughout the four-year Bachelor's program each student has

- one week's entrance examinations

- 122 weeks of lectures, labs, design work and class discussions

20 weeks of field work

11 weeks involving writing and discussion of a thesis

12 weeks in examinations

one week for "public good", such as planting flowers and trees on the campus

one week's physical labour with workers or farmers

- $32-1 / 2$ weeks holidays and vacations

Required courses include

- 670 hours of maths, physics, solid mechanics, and chemistry

- 1050 hours of physical geology, crystallography and mineralogy, optical mineralogy, petrology, paleontology, historical and structural geology, mineral deposits, regional geology, geomorphology and Quaternary geology.

- 210 hours of philosophy and social sciences

140 hours of physical training (in first and second years)

- 300 hours of a for eign language

Selected courses (200 hours for fourth year students and 300 for the best among these) include

- tectonics

- structures in oil fields

- geomechanics

sedimentary facies and palaeogeography

. stratigraphy

- Quaternary chronology

- neotectonics

- oceanic geology

- introductory geophysics

- exploration for and prediction of mineral deposits

- basic physics of remote sensing

- remote sensing in geology

- processing and classification of remote sensing geology

- basic computer science

Wuhan college has seven separate departments, eleven research sections, a Center of Applied Research on Minerals and Rocks, and a Computer Station. More than 70 key research projects for the Ministry of Geology and Mineral Resources and for several other Ministries have been undertaken by College faculty members in addition to some 60 projects of their own. Three professors are leaders of the Chinese working groups in three IGCP projects.

Other colleges of geology specialize in different research topics and emphasize such courses as economic management of geology, or mineral surveys and exploration. Geological departments in Chinese universities have fewer specialities but wider scope. They place more emphasis on mathematics, physics, chemistry and foreign languages, and less on exploration techniques and methods. The students, as compared with those in colleges of geology, spend less time in field work, but about the same time in research. Students studying for a master's degree, for example, will spend half of their two or three years in taking courses and the other half on the thesis. They also have to complete courses in the "dialectics of nature" and two foreign languages. Doctoral candidates devote most of the time to their dissertation.

Geological education, whether in colleges, universities or in schools, aims at training geologists morally, intellectually and physically. At the same time, the training develops their originality and ability to work independently in order to meet the challenge of an ever-changing scientific world. To encourage geological field investigations, student expeditions are sometimes formed joining with other groups in mountainclimbing organized by the State Physical Culture and Sports commission. The teaching calendar can be readjusted on such occasions to ensure the students' success.

Individual interests and specialities, as well as national needs are taken into consideration when the government assigns students to jobs. There are no worries about unemployment and most of them can get a desirable job. Many graduates volunteer to work where they are most needed, as in frontier areas or where living conditions are difficult.

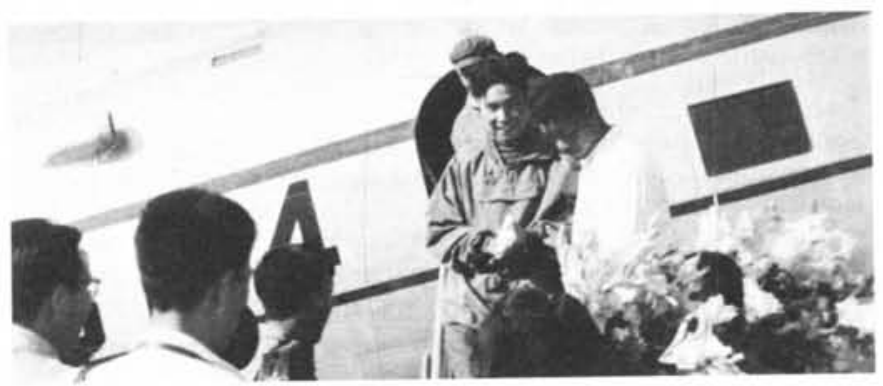

Wana Fu-zhou, a student of Beijing College of Geology, was greeted in Beijing just after he had reached the summit of Zhumulangma (Mt. Everest), Xizanq (Tibet) in 1960.

\section{International Exchanges}

In recent years there has been an increasing number of international academic exchanges by which other countries send their students to study geology in some of China's colleges and China also sends geology students abroad for their degrees. Of course, many foreign scholars come to China from abroad, giving visiting lectures in the universities and colleges, or attending symposia on geology. Educational and academic exchanges between governments as well as academic organizations are welcomed by China's geological circle, for geologists in China treasure the chance to learn from their colleagues abroad. As China's economic situation improves, the future of these exchanges looks bright. China's geological education is forging ahead.

\section{ABOUT THE AUTHOR:}

Professor Chi Ji-shang is a Vice-President of Wuhan College of Geology (Chengfu Road, Beijing, People's Republic of China) where she is attached to the Petrology Research Section. She received her doctorate in 1949 for petrofabric studies on the Wissahickon Schists of Pennsylvania, though her current interests relate to kimberlites. Professor Chi is a member of the IGCP Board.

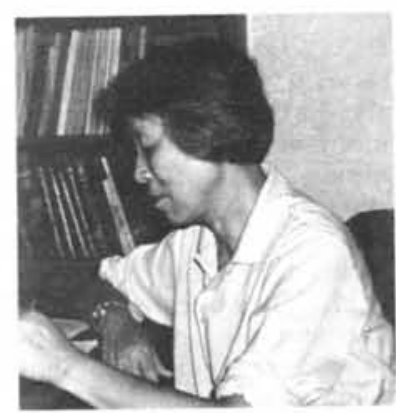

